\title{
BIOÉTICA Y BIODERECHO
}

\section{Diego Gracia}

\author{
Presidente de la Fundación de Ciencias de la Salud
}

Hoy se ha convertido en tópico hermanar ambos términos. A fin de cuentas, la ética y el derecho son los dos sistemas normativos de que dispone toda sociedad. Las diferencias entre uno y otro, por lo demás, no acaban de estar claras. En una sociedad perfecta parece que debieran coincidir. De hecho, así pensó gran parte de la cultura occidental, desde sus mismos orígenes en la antigua Grecia. Lo que la razón dicta como correcto o incorrecto, eso es lo que debería convertirse en ley. El Derecho "natural" se expresaría así como Derecho "positivo". Esto explica que en algunos idiomas, como el inglés, una misma palabra, right, sirva para designar tanto lo éticamente correcto como lo jurídicamente justo. Así ha venido pensando la cultura occidental desde que el naturalismo estoico hizo sentir su influjo en los jurisconsultos romanos. $\mathrm{Y}$ el Derecho romano ha sido la matriz del derecho positivo propio de los países descendientes del gran Imperio romano.

En el llamado "iusnaturalismo", todo es derecho. Está, en primer lugar, el derecho natural, que para esta corriente es el nombre propio de la ética. Y de él dimana el único derecho positivo que cabe considerar legítimo. De donde resulta que ética y derecho acaban fundiéndose hasta confundirse. En la cultura occidental, a partir de Roma, la ética no la han hecho los filósofos sino los jurisconsultos y canonistas. En el mundo católico, esa tradición se ha mantenido hasta, cuando menos, mediado el siglo $\mathrm{XX}$.

Pero en el mundo moderno tal modo de pensar y proceder no podía resultar incólume. Entre otras razones, porque las guerras de religión modernas habian hecho nacer un fenómeno nuevo, el "pluralismo". El pluralismo lo es siempre de valores. Hay personas con diferentes códigos éticos, y todas reclaman respeto. Del monismo se pasa al pluralismo, y de la intolerancia al respeto. Se impone el código múltiple, frente al anterior código único. La ley positiva deberá proteger esa pluralidad, con lo cual habrá de ser también plural. Cuius regio eius religio. Empieza a tambalearse la vieja teoría del derecho natural homogéneo y universal. Y la ética cobra autonomía respecto del derecho. El representante paradigmático de esta nueva situación fue Kant. La ética es interna, dice, en tanto que el derecho sólo obliga externamente, a cumplir con la sanción en caso de incumplimiento. El principio de la moralidad es otro, el "deber", Pflicht. En una situación ideal, ética y derecho coincidirían, porque éste consistiría en la positivización de los deberes dictados por la ética. Pero en las sociedades históricas eso no es así. Vivimos aún de modo casi salvaje, en "estado de naturaleza". Todavía no hemos llegado a la "sociedad cosmopolita".

En la época del pluralismo ya no resultaba posible basarlo todo en el viejo derecho natural. La legitimidad debía venir del procedimiento, el que las leyes estuvieran 
elaboradas por parlamentos representativos de la soberanía popular. Muerto el derecho natural, cobró vida el derecho positivo. La razón dictará a los parlamentarios las leyes que tienen que aprobar, que, obviamente, no tendrán por qué coincidir en los distintos lugares de la tierra. La diversidad enriquece. Y un principio moral básico de la modernidad es el respeto de las diferencias.

Así pensó, más o menos, el siglo XIX. En el XX las cosas empezaron a torcerse. Comenzó con una guerra, la que llamaron Gran Guerra, que muchos vieron como la tumba de los ideales decimonónicos. En vez de conducirnos al mundo feliz, se había desatado el poder de todas las furias. Era preciso dar un golpe de timón. Y vinieron los totalitarismos, dispuestos a remediar la molicie del parlamentarismo decimonónico. Ahí debía estar la solución. Los hubo azules y rojos. Y de nuevo la sorpresa de una guerra que por primera vez en la historia hubo que calificar de mundial. Otra decepción, esta aún mayor que la anterior. Si algo quedó claro tras ella fue que el puro iuspositivismo no conducía a nada bueno. ¿Qué hacer, retornar al viejo iusnaturalismo? ¿O dar con una vía intermedia que hiciera de puente entre ética y derecho? Al menos desde la época de Locke había ido tomando cuerpo la doctrina de los "derechos humanos". ¿Por qué no hacer una Declaración Universal de Derechos Humanos, que sirviera de marco a todo el derecho positivo? Y así lo aprobó la Asamblea General de las Naciones Unidas el 10 de diciembre de 1948. No cualquier derecho positivo es legítimo por el mero hecho de considerarse legal. La legitimidad vendría dada por el atenimiento y respeto de los derechos humanos.

Esta es nuestra historia, que, cuando menos, hay que calificar de confusa. ¿Ética o derecho? ¿Cuál va primero? Si alguna lección cabe sacar de todo lo acontecido es que el mero derecho positivo, por muy soberanas que se consideren las cámaras que lo aprueban, no está sin más dotado de legitimidad. Tiene que someterse a unos ciertos principios que, por pura lógica, han de ser extrajurídicos, o mejor, metajurídicos. La época de Kelsen ya no es la nuestra. ¿Cuáles pueden ser estos? La tesis más extendida en los teóricos de la segunda mitad del siglo $X X$ ha sido que ya no pueden ser principios "sustantivos", como en el viejo iusnaturalismo, razón por la que han dado en llamarles "procedimentales". Así, en Rawls, en Habermas y en la larga lista de sus secuaces. Otros, como Gregorio Peces-Barba, creyeron encontrar la solución en las "ideas reguladoras" de Kant, y pensaron que la función del derecho no es otra que positivizar y operativizar las "pretensiones básicas de la humanidad", constituidas por los valores de "dignidad humana", "libertad", "igualdad", "solidaridad" y "seguridad jurídica". Por una vía o por otra, parece que al final se llega al mismo punto: el derecho es un epifenómeno de algo anterior a él, que es la moralidad, la ética. Dime cuáles son los valores de una sociedad y te diré qué leyes aprobará su parlamento.

Moraleja. Cada vez resulta más necesario distinguir la Sociedad del Estado, y la Ética del Derecho, algo que a lo largo de nuestra historia ha sido, cuando menos, confuso. No, la sociedad y el Estado no son lo mismo, como tampoco la Ética y el Derecho. La ética es el lenguaje de la sociedad, de igual modo que la ley lo es del Estado. Y, como ya dijera Hegel y tras él se ha repetido cada vez con más fuerza, el Estado es una superestructura surgida de la sociedad, y el derecho un epifenómeno de la ética. Las leyes se promulgan, y la conducta moral se educa. Las sociedades se construyen y destruyen no en los parlamentos sino en las escuelas. Las grandes olvidadas. 